\title{
PENERAPAN MODEL PEMBELAJARAN KOOPERATIF TIPE TALKING STICK BERBANTUAN MEDIA QUESTION BOX UNTUK MENINGKATKAN HASIL BELAJAR IPS SISWA KELAS III SDN 161 PEKANBARU
}

\author{
Nadila Aulia Vista, Neni Hermita, Zufriady \\ Pendidikan Guru Sekolah Dasar FKIP Universitas Riau \\ nadila.aulia317@gmail.com,nenihermita1@gmail.com,zufriady@lecturer.unri.ac.id
}

\begin{abstract}
The background of this study is caused by third-grade students' low learning outcome in SDN 161 Pekanbaru. It is indicated by their social science test scores from 24 students. A minimum completeness criterion in this school is 75 , but the number of students who score above this criterion is 8 students, and 16 students are below the criteria. The average score is 66.46. To solve this problem, the researchers apply a talking stick cooperative learning model assisted by question box media. This model is believed in supporting teachers in improving the learning activities because it can build a better classroom atmosphere that triggers students' spirit and make students more active to express their opinions. Media use also makes students more interested in the learning process and stimulate students' emotional and intellectual involvement. This study applies the classroom action research that consists of two cycles. The subject is the third-grade students at SDN 161 Pekanbaru. After the implementation of the classroom action research, students' learning outcomes increase from 66.46 to 75.83 in the first cycle (increase 14.10\%), and 82.92 in the second cycle (increase $24.77 \%$ from the initial score). So, the implementation of the talking stick cooperative learning model assisted by question box media can increase third-grade students' social science learning outcomes in SDN 161 Pekanbaru.
\end{abstract}

Keywords: Cooperative Model, Type Talking Stick, Learning Outcomes of IPS

\section{PENDAHULUAN}

IImu pengetahuan sosial (IPS) adalah ilmu yang didalamnya membahas kegiatan manusia secara ilmiah dan memberikan wawasan untuk dapat dipahami oleh anak yang sedang dalam pendidikan di jenjang dasar dan menengah. Menurut Zulkifli, dkk (2009:2) istilah IPS di sekolah dasar merupakan nama mata pelajaran yang berdiri sendiri sebagai integrasi dari sejumlah konsep disiplin ilmu sosial, humaniora, sains bahkan sebagai isu dan masalah sosial kehidupan.

Proses pembelajaran IPS memerlukan model pembelajaran yang bervariasi karena setiap model pembelajaran belum tentu dapat digunakan dalam semua materi. Kenyataan yang terjadi pada saat ini dikelas, dalam mengajar guru kurang

Nadila Aulia Vista, Penerapan Model Pembelajaran Kooperatif Tipe Talking Stick Berbantuan Media Question Box Untuk Meningkatkan Hasil Belajar IPS Siswa Kelas III SDN 161 Pekanbaru 
memahami metode-metode pembelajaran yang digunakan serta tidak adanya penggunaan model pembelajaran. Karena alasan tersebut dapat memberi pengaruh pada hasil belajar siswa.

Berdasarkan observasi dengan Ibu Sinta Sitorus, S. Pd selaku wali kelas IIIA SDN 161 Pekanbaru pada tahun ajaran 2018/2019, hasil belajar IPS masih tergolong rendah hasil belajar siswa pada mata pelajaran IPS. Rendahnya hasil belajar siswa tersebut terlihat pada rata-rata kelas yaitu 66,46, dari 24 orang hanya 8 orang $(33,33 \%)$ yang tuntas dan 16 orang $(66,67 \%)$ yang tidak tuntas. Standar KKM dari sekolah adalah 75. . Nilai siswa dalam pelajaran IPS belum memenuhi KKM yang ditetapkan oleh sekolah. Hal ini terjadi karena proses belajar mengajar yang berlangsung di kelas kurang menyenangkan. Hal ini terlihat dari kenyataan yang terjadi dikelas guru hanya menggunakan metode konvensional dan kurang melibatkan siswa dalam pembelajaran dan kurang memahami metode-metode pembelajaran yang digunakan serta tidak adanya penggunaan model pembelajaran. Akibatnya pembelajaran cenderung monoton, sebagian besar siswa kurang memperhatikan pembelajaran ketika penyampaian materi, siswa kurang berani mengungkapkan pendapatnya, dan siswa kurang aktif dalam proses pembelajaran karena siswa tidak dilibatkan dalam proses pembelajaran tersebut.

Berdasarkan hal tersebut, proses pembelajaran menjadi kurang bermakna karena siswa kurang memahami materi yang diajarkan ketika proses pembelajran berlangsung. Hal ini tentu sangat berpengaruh terhadap hasil belajar siswa. Melihat permasalahan tersebut, salah satu upaya yang dapat dilaksanakan yaitu dengan menggunakan model pembelajaran kooperatif tipe Talking Stick berbantuan media question box. Pemilihan model tersebut diyakini mampu membantu guru dalam memperbaiki kegiatan pembelajaran karena dapat membangun suasana kelas yang memancing semangat siswa, membuat siswa lebih aktif dalam mengemukakan pendapat, membuat pembelajaran menjadi leibh menyenangkan dan membuat siswa ikut terlibat dalam proses pembelajaran. Penggunaan media juga membuat siswa lebih tertarik terhadap proses pembelajaran dan merangsang keterlibatan emosi dan intelektual siswa. 
Model pembelajaran kooperatif tipe talking stick menurut Imas Kurniasih dan Berlin Sani (2015:82) merupakan satu dari sekian banyak model pembelajaran kooperatif. Model pembelajaran ini dilakukan dengan berbantuan tongkat. Tongkat dijadikan sebagai jatah atau giliran untuk berpendapat atau menjawab pertanyaan dari guru setelah siswa mempelajari materi pelajaran. Langkah-langkah model pembelajaran kooperatif tipe talking stick adalah sebagai berikut: (a) Guru menjelaskan tujuan pembelajaran pada saat itu. (b) Guru membentuk kelompok yang terjadi atas 5 orang. (c) Guru menyiapkan sebuah tongkat yang panjangnya $20 \mathrm{~cm}$. (d) Setelah itu, guru menyampaikan materi pokok yang akan dipelajari, kemudian memberikan kesempatan pada kelompok untuk membaca dan mempelajari materi pelajaran tersebut dalam waktu yang telah ditentukan. (e) Siswa berdiskusi membahas masalah yang terdapat didalam wacana. (f) Setelah kelompok selesai membaca materi pelajaran dan mempelajari isinya, guru mempersilahkan anggota kelompok untuk menutup isi bacaan. (g) Guru mengambil tongkat dan memberikan kepada salah satu anggota kelompok, setelah itu guru memberikan pertanyaan dan anggota kelompok yang memegang tongkat tersebut harus menjawabnya, demikian seterusnya sampai sebagian besar siswa mendapat bagian untuk menjawab setiap pertanyaan dari guru. (h) Siswa lain boleh membantu menjawab pertanyaan jika anggota kelompoknya tidak bisa menjawab pertanyaan. (i) Setelah semuanya mendapat giliran, guru mendapat giliran, guru membuat kesimpulan dan melakukan evaluasi, baik individu ataupun secara kelompok. Dan setelah itu menutup pelajaran.

Media question box adalah media pembelajaran sederhana yang dibuat berbentuk kotak yang didalamnya berisi sejumlah pertanyaan yang akan diambil tiap-tiap anggota kelompok secara acak. Media ini merupakan media tiga dimensi (3D) yang tampilannya dapat diamati dari arah pandang mana saja, dan mempunyai dimensi panjang, lebar, dan tinggi (Rayanda Asyhar, 2012:47). Media ini dibuat untuk menarik minat siswa untuk belajar serta mengkondisikan seluruh anggota kelompok untuk aktif bekerja menyelesaikan tugas.

Pelaksanaan model pembelajaran talking stick yaitu guru membagi kelompok, kemudian siswa diminta untuk mengerjakan tugas kelompok dan mempelajari materi bersama dengan kelompoknya. Setelah mempelajari materi, 
siswa diminta untuk menutup buku. Guru mempersiapkan tongkat lalu memberikan tongkat pada salah satu siswa. Siswa yang mendapatkan tongkat ketika musik berhenti harus mengambil dan menjawab pertanyaan dari media question box.

Berdasarkan latar belakang permasalahan tersebut, maka penelitian ini bertujuan untuk mengetahui: peningkatan hasil belajar IPS dengan penerapan model pembelajaran kooperatif tipe talking stick berbantuan media question box.

\section{METODE PENELITIAN}

Penelitian ini dilaksanakan dikelas IIIA SDN 161 Pekanbaru pada semester ganjil tahun ajaran 2018/2019 pada mata pelajaran IPS. Subjek penelitian ini adalah siswa kelas IIIA SDN 161 Pekanbaru yang berjumlah 24 siswa yang terdiri dari 12 laki-laki dan 12 perempuan. Penelitian ini dilaksanakan pada tanggal 01 Agustus sampai dengan 11 Agustus 2018. Metode yang digunakan pada penelitian di SDIT Insan Utama Pekanbaru adalah Penelitian Tindakan Kelas (Classroom Action Research). Penelitian tindakan kelas ini dilaksanakan selama 2 siklus. Pada setiap satu siklus terdiri dari 3 kali pertemuan yaitu 2 kali materi dan 1 kali ulangan harian. Menurut Suharsimi Arikunto (Lazim N, dkk 2018; Nurmi dkk: 2018). penelitian tindakan kelas adalah suatu pencermatan terhadap kegiatan belajar berupa sebuah tindakan yang sengaja dimunculkan dan terjadi dalam sebuah kelas. Desain penelitian tindakan kelas adalah model siklus dengan dua siklus, yaitu siklus I dan siklus II. Siklus I terdiri dari: perencanaan, pelaksanaan, pengamatan, dan refleksi. Hasil penelitian pada siklus I akan diadakan perbaikan proses pembelajaran pada siklus II. Instrumen dalam penelitian ini adalah perangkat pembelajaran yang terdiri dari silabus, RPP, LKS dan evaluasi. Instumen pengumpulan data terdiri dari tes hasil belajar siswa dan lembar observasi.

\section{HASIL PENELITIAN}

\section{Hasil Belajar}

Hasil belajar siswa yang didapatkan setelah melakukan ulangan harian pada siklus I dan II pada materi cara dan manfaat memelihara lingkungan alam 
dan buatan mengalami peningkatan. Peningkatan hasil belajar tersebut dapat dilihat pada tabel berikut ini:

\section{Tabel 1}

Peningkatan Hasil Belajar Siswa Sebelum dan Sesudah Tindakan

\begin{tabular}{|c|c|c|c|c|}
\hline No & Aspek & Rata-rata & Peningkatan & $\begin{array}{c}\text { Persentase } \\
\text { Peningkatan }\end{array}$ \\
\hline 1. & Skor Dasar & 66,46 & - & - \\
\hline 2. & UH I & 75,83 & 9,37 & $14,10 \%$ \\
\hline 3. & UH II & 82,92 & 16,46 & $24,77 \%$ \\
\hline
\end{tabular}

Berdasarkan tabel tersebut, dapat dilihat peningkatan hasil belajar dari skor dasar yang hanya 66,46 dan setelah tindakan dilakukan hasil belajar siswa mengalami peningkatan yang dilihat pada siklus I yaitu 75,83 meningkat dari skor dasar sebesar 9,37 dengan persentase peningkatan sebesar 14,10\% dan siklus II meningkat lagi sebesar 16,46 dari skor dasar menjadi 82,92 dengan persentase peningkatan sebesar $24,77 \%$.

Ketuntasan individu dan klasikal juga mengalami peningkatan yang dapat dilihat pada tabel berikut :

Tabel 2

Ketuntasan Individu dan Klasikal

\begin{tabular}{|c|c|c|c|c|c|}
\hline Aspek & Jumlah & \multicolumn{2}{|c|}{ Ketuntasan individu } & \multicolumn{2}{c|}{ Ketuntasan klasikal } \\
\cline { 3 - 6 } & Siswa & $\begin{array}{c}\text { Siswa } \\
\text { Tuntas }\end{array}$ & $\begin{array}{c}\text { Siswa Tidak } \\
\text { Tuntas }\end{array}$ & $\begin{array}{c}\text { Persentase } \\
\text { Ketuntasan }\end{array}$ & Kategori \\
\hline Skor Dasar & 24 & 8 & 16 & $33,33 \%$ & TT \\
\hline UH Siklus I & 24 & 17 & 7 & $70,83 \%$ & TT \\
\hline UH Siklus II & 24 & 21 & 3 & $87,50 \%$ & T \\
\hline
\end{tabular}

Berdasarkan tabel tersebut, ketuntasan individu dan klasikal juga mengalami peningkatan. Hal ini dapat dilihat dari sebelum dilakukan tindakan jumlah siswa yang tuntas hanya 8 orang dengan persentase $33,33 \%$ dengan kategori tidak tuntas kemudian setelah dilaksanakan tindakan dengan menerapkan model 
pembelajaran kooperatif tipe talking stick berbantuan media question box pada siklus I jumlah siswa yang tuntas meningkat menjadi 17 orang dengan persentase $70,83 \%$ dengan kategori tidak tuntas. Pada siklus II terjadi peningkatan lagi jumlah siswa yang tuntas menjadi 21 orang dengan persentase $87,50 \%$ dengan kategori tuntas. Ketuntasan klasikal dikatakan tuntas apabila telah mencapai $85 \%$ dari jumlah siswa yang tuntas.

\section{Keterlaksanaan Model Pembelajaran Talking Stick Berbantuan Media Question Box}

\section{Aktivitas Guru}

Berdasarkan data yang diperoleh dari hasil observasi aktivitas guru yang terdiri atas 4 kali pertemuan pembelajaran selama proses pembelajaran berlangsung dengan penerapan model pembelajaran kooperatif tipe Talking Stick berbantuan media Question Box di kelas IIIA SDN 161 Pekanbaru tahun pelajaran 2018/2019. Pelaksanaan model pembelajaran kooperatif tipe Talking Stick berbantuan media Question Box telah dilakukan dengan baik dan mendapatkan hasil sesuai yang diharapkan. Hal ini dapat dilihat pada tabel berikut ini:

\section{Tabel 4}

Analisis Lembar Observasi Aktivitas Guru pada siklus I dan siklus II

\begin{tabular}{|l|l|c|c|c|c|}
\hline No. & \multicolumn{1}{|c|}{ Aspek } & \multicolumn{2}{|c|}{ Siklus I } & \multicolumn{2}{c|}{ Siklus II } \\
\cline { 3 - 6 } & & Pertemuan & Pertemuan & Pertemuan & Pertemuan 2 \\
& & 1 & 2 & 1 & \\
\hline 1. & Jumlah skor & 18 & 19 & 20 & 22 \\
\hline 2. & Persentase & $75 \%$ & $79,17 \%$ & $83,33 \%$ & $91,67 \%$ \\
\hline 3. & Kategori & Cukup & Baik & Baik & Sangat Baik \\
\hline
\end{tabular}

Berdasarkan dapat dijelaskan bahwa pertemuan pertama siklus I pada lembar aktivitas guru mendapatkan skor 18 dengan persentase $75 \%$ dengan kategori cukup, kemudian pada pertemuan kedua siklus I aktivitas guru mendapatkan skor 19 dengan persentase 79,17\% dengan kategori baik. Pada pertemuan pertama siklus II aktivitas guru meningkat dengan mendapatkan skor 21 dengan persentase $83,33 \%$ dan kategori baik, sedangkan pada pertemuan 
kedua siklus II juga mengalami meningkat dengan mendapatkan skor 22 dengan persentase $91,67 \%$ dengan kategorikan sangat baik. Peningkatan aktivitas guru yang terjadi disetiap pertemuan ini disebabkan guru selalu memperbaiki kekurangan-kekurangan yang dilakukan pada setiap pertemuan.

\section{Aktivitas Siswa}

Berdasarkan data yang diperoleh dari hasil observasi aktivitas siswa yang terdiri atas 4 kali pertemuan pembelajaran selama proses pembelajaran berlangsung dengan penerapan model pembelajaran kooperatif tipe Talking Stick berbantuan media Question Box di kelas IIIA SDN 161 Pekanbaru tahun pelajaran 2018/2019. Pelaksanaan model pembelajaran kooperatif tipe Talking Stick berbantuan media Question Box telah dilakukan dengan baik dan mendapatkan hasil sesuai yang diharapkan. Hal ini dapat dilihat pada tabel berikut ini:

Tabel 5

Analisis Lembar Observasi Aktivitas Siswa pada siklus I dan siklus II

\begin{tabular}{|c|c|c|c|c|c|}
\hline No. & Aspek & \multicolumn{2}{|c|}{ Siklus I } & \multicolumn{2}{c|}{ Siklus II } \\
\cline { 3 - 6 } & & Pertemuan 1 & Pertemuan 2 & Pertemuan & Pertemuan 2 \\
& & & 1 & \\
\hline 1. & Jumlah skor & 17 & 18 & 20 & 22 \\
\hline 2. & Persentase & $70,83 \%$ & $75,00 \%$ & $83,33 \%$ & $91,67 \%$ \\
\hline 3. & Kategori & Cukup & Cukup & Baik & Sangat Baik \\
\hline
\end{tabular}

Berdasarkan tabel diatas dapat dilihat aktivitas siswa selama 4 kali pertemuan juga mengalami peningkatan. Pada pertemuan pertama siklus I mendapatkan skor 17 dengan persentase 70,83\% dan kategori cukup, lalu pada pertemuan kedua siklus I mendapatkan skor 18 dengan persentase $75,00 \%$ dengan kategori cukup. Kemudian pada pertemuan pertama siklus II terjadi peningkatan dengan mendapatkan skor 20 dengan persentase 83,33\% dan kategori baik, lalu pada pertemuan kedua siklus II meningkat dengan mendapatkan skor 22 dengan persentase 91,67\% dengan kategori sangat baik.

\section{PEMBAHASAN HASIL PENELITIAN}

Nadila Aulia Vista, Penerapan Model Pembelajaran Kooperatif Tipe Talking Stick Berbantuan Media Question Box Untuk Meningkatkan Hasil Belajar IPS Siswa Kelas III SDN 161 Pekanbaru 
Setelah dilakukan penelitian pada bulan Agustus tahun 2018 dikelas III SDN 161 Pekanbaru dengan menerapkan model pembelajaran kooperatif tipe Talking Stick berbantuan media question box dengan materi cara dan manfaat memelihara lingkungan alam dan buatan pada mata pelajaran IPS telah diketahui dalam analisis data bahwa aktivitas guru, aktivitas siswa dan hasil belajar siswa telah mengalami peningkatan.

Model pembelajaran kooperatif tipe talking stick ini merupakan model pembelajaran yang dapat membuat masing-masing siswa memahami materi. Dan dalam pelaksanaannya sebagian besar siswa mendapat giliran dalam menjawab pertanyaan, sehingga dapat melatih keberanian masing-masing siswa dalam berbicara di depan teman-teman sekelasnya.

Ketercapaian hasil belajar IPS secara individu dan klasikal setelah menerapkan model pembelajaran kooperatif tipe talking stick berbantuan media question box terlihat ada peningkatan yang terjadi disetiap siklusnya dibandingkan dengan sebelum dilaksanakan tindakan. Terlihat dari skor dasar yang hanya 66,46 dan setelah tindakan dilakukan hasil belajar siswa mengalami peningkatan yang dilihat pada siklus I yaitu 75,83 meningkat dari skor dasar sebesar 9,37 dan siklus II meningkat sebesar 16,46 dari skor dasar menjadi 82,92. Ketuntasan individu dan klasikal juga mengalami peningkatan terlihat dari sebelum dilakukan tindakan jumlah siswa yang tuntas hanya 8 orang dengan persentase $33,33 \%$ kemudian setelah dilaksanakan tindakan pada siklus I jumlah siswa yang tuntas meningkat menjadi 17 orang dengan persentase $70,83 \%$. Pada siklus II terjadi peningkatan lagi jumlah siswa yang tuntas menjadi 21 orang dengan persentase $87,50 \%$.

Berdasarkan dari penjelasan tersebut, hasil belajar sebelum dan sesudah diberi tindakan yang peneliti lakukan sudah terjadi peningkatan sesuai yang diharapkan. Peningkatan yang terjadi dikarenakan refleksi yang dilakukan setiap akhir siklus, pembelajaran ini tidak monoton, dan siswa sudah terbiasa dengan model pembelajaran ini seperti melakukan permainan dengan tongkat sehingga kelas menjadi menyenangkan dan tidak menegangkan. Jadi siswa menjadi lebih berani dan mampu berbicara untuk menjawab pertanyaan yang diberikan dalam media question box. Hal ini sesuai dengan teori yang dijelaskan oleh Imas Kurniasih dan Berlin Sani (2015:82) bahwa model pembelajaran talking stick 
merupakan satu dari sekian banyak model pembelajaran kooperatif. Model pembelajaran ini dilakukan dengan berbantuan tongkat. Tongkat dijadikan sebagai jatah atau giliran untuk berpendapat atau menjawab pertanyaan dari guru setelah siswa mempelajari materi pelajaran.

Dengan demikian hipotesis yang diajukan dapat diterima. Bahwa penerapan model pembelajaran kooperatif tipe Talking Stick berbantuan media question box dapat meningkatkan hasil belajar IPS siswa kelas III SDN 161 Pekanbaru.

\section{SIMPULAN}

Berdasarkan hasil penelitian yang diperoleh setelah menerapkan model pembelajaran kooperatif tipe Talking Stick berbantuan media question box pada siswa kelas III SDN 161 Pekanbaru diketahui hasil belajar siswa kelas III SDN 161 Pekanbaru mengalami peningkatan. Hal ini dapat dilihat dari data berikut:

1. Aktivitas guru pada pertemuan pertama siklus I persentasenya adalah $75,00 \%$ dengan kategori cukup, meningkat pada pertemuan kedua siklus I persentasenya $79,17 \%$ dengan kategori baik. Pada pertemuan pertama siklus II persentasenya $83,33 \%$ dengan kategori baik kemudian meningkat lagi pada pertemuan kedua siklus II persentasenya adalah 91,67\% dengan kategori sangat baik. Aktivitas siswa juga mengalami peningkatan. Pada pertemuan pertama siklus I persentasenya adalah $70,83 \%$ dengan kategori cukup, meningkat pada pertemuan kedua siklus I persentasenya yaitu $75,00 \%$ dengan kategori baik. Pada pertemuan pertama siklus II persentasenya yaitu 83,33\% dengan kategori baik dan meningkat lagi pada pertemuan kedua siklus II persentasenya adalah $91,67 \%$ dengan kategori sangat baik.

2. Ketuntasan klasikal pada skor dasar sebelum dilakukan penelitian adalah 33,33\% kemudian setelah dilaksanakan penelitian pada UH siklus I ketuntasan klasikal meningkat menjadi $70,83 \%$ lalu meningkat lagi pada UH siklus II menjadi $87,50 \%$. Rata-rata hasil belajar siswa juga mengalami peningkatan dari sebelum dilakukan penelitian adalah 66,46 meningkat menjadi 75,83 pada $\mathrm{UH}$ siklus I dengan peningkatan dari skor dasar sebesar 9,37 dengan persentase 14,10\%. Kemudian pada UH siklus II, rata-rata hasil belajar siswa meningkat 
lagi menjadi 82,92 dengan peningkatan dari skor dasar sebesar 16,46 dengan persentase $24,77 \%$.

\section{DAFTAR PUSTAKA}

Arikunto, Suharsimi, dkk. 2010. Penelitian Tindakan Kelas.Sinar Grafika Offset. Jakarta

Asyhar, Rayanda. 2011. Kreatif Mengembangkan Media Pembelajaran.Gaung Persada (GP) Press. Jakarta.

Kurniasih, Imas, Berlin Sani. 2015. Ragam Pengembangan Model Pembelajarn untuk peningkatan Profesionalitas Guru. Kata Pena. Jakarta.

Lazim, N. dkk. 2018. Utilizing Cooperative Learning Model Types Make a Match to Promote Primary Students' Achivement in Science. Vol.1 No. 1, hlm11-19.

Nurmi. dkk. 2018. Enhancing Primary Students' Science Learning Outcome Utilizing Visual Multimedia. Vol.1 No. 2, hlm 109-115.

Zulkifli, dkk. 2009. Konsep Dasar IPS. PGSD FKIP Universitas Riau 